\title{
Hypocalcemia in Dairy Cows: Meta-analysis and Dietary Cation Anion Difference Theory Revisited
}

\author{
I. J. Lean, ${ }^{\star 1}$ P. J. DeGaris, ${ }^{\star}$ D. M. McNeil,† and E. Blockł \\ *Bovine Research Australasia, Camden 2570, NSW, Australia \\ †MC Franklin Laboratory, Department of Veterinary Science, University of Sydney, Australia \\ $\ddagger$ Church \& Dwight Co., Inc., Arm \& Hammer Animal Nutrition Group, Princeton, NJ 08543
}

\begin{abstract}
Data from 137 published trials involving 2,545 calvings were analyzed using random effects normal logistic regression models to identify risk factors for clinical hypocalcemia in dairy cows. The aim of the study was to examine which form, if any, of the dietary cation anion difference (DCAD) equation provided the best estimate of milk fever risk and to clarify roles of calcium, magnesium, and phosphorus concentrations of prepartum diets in the pathogenesis of milk fever. Two statistically equivalent and biologically plausible models were developed that predict incidence of milk fever. These models were validated using data from 37 trials excluded from the original data used to generate the models; missing variables were replaced with mean values from the analyzed data. The preferred models differed slightly; Model 1 included prepartum DCAD, and Model 2 included prepartum dietary concentrations of potassium and sulfur alone, but not sodium and chloride. Other factors, included in both models were prepartum dietary concentrations of calcium, magnesium, phosphorus; days exposed to the prepartum diet; and breed. Jersey cows were at 2.25 times higher risk of milk fever than Holstein cows in Model 1. The results support the DCAD theory of greater risk of milk fever with higher prepartum dietary DCAD (odds ratio = 1.015). The only DCAD equation supported in statistical analyses was $\left(\mathrm{Na}^{+}+\mathrm{K}^{+}\right)-\left(\mathrm{Cl}^{-}+\mathrm{S}^{2-}\right)$. This finding highlights the difference between developing equations to predict DCAD and those to predict milk fever. The results support a hypothesis of a quadratic role for $\mathrm{Ca}$ in the pathogenesis of milk fever (model 1, odds ratio = 0.131; Model 2, odds ratio $=0.115$ ). Milk fever risk was highest with a prepartum dietary concentration of $1.35 \%$ calcium. Increasing prepartum dietary magnesium concentrations had the largest effect on decreasing incidence of milk fever in both Model 1 (odds ratio = 0.006 ) and Model 2 (odds ratio $=0.001$ ). Increasing
\end{abstract}

Received May 30, 2005.

Accepted September 6, 2005.

${ }^{1}$ Corresponding author: ianl@dairydocs.com.au dietary phosphorus concentrations prepartum increased the risk of milk fever (Model 1, odds ratio = 6.376; Model 2, odds ratio $=9.872$ ). The models presented provide the basis for the formulation of diets to reduce the risk of milk fever and strongly support the need to evaluate macro mineral nutrition apart from DCAD of the diet.

Key words: milk fever, meta-analysis, dairy cow, dietary cation-anion difference

\section{INTRODUCTION}

Metabolic factors that influence the risk of hypocalcemia of the dairy cow remain a matter of debate. Recently, there have been several comprehensive reviews of hypocalcemia in dairy cows (Horst et al., 1997; Goff, 2000; Oetzel, 2000; McNeill et al., 2002; Thilsing-Hansen et al., 2002; Lean et al., 2003). Areas of contention identified from these reviews include the most appropriate equation for use in predicting $\mathrm{DCAD}$ of the prepartum diet and the roles of dietary magnesium, phosphorus and calcium concentrations in the pathogenesis of hypocalcemia.

Meta-analysis, the quantitative analysis of previous studies, provides opportunities to investigate previously proposed hypotheses and to develop new hypotheses from large databases. In the study of disorders of relatively low incidence, such as milk fever, the availability of large numbers of observations provided by meta-analysis is useful for evaluating the effect on disease of factors that have physiologic effect. One such factor is DCAD. The DCAD equation cited by Ender et al. (1962) and used by Block (1984) $\left\{\mathrm{DCAD}=\left(\mathrm{Na}^{+}+\right.\right.$ $\left.\mathrm{K}^{+}\right)-\left(\mathrm{Cl}^{-}+\mathrm{S}^{2-}\right)$ [Equation 1]\} is the most commonly used form of the equation. Horst et al. (1997) recommended that other anions and cations be included in the equation and proposed DCAD $=\left(0.38 \mathrm{Ca}^{2+}+0.3\right.$ $\left.\mathrm{Mg}^{2+}+\mathrm{Na}^{+}+\mathrm{K}^{+}\right)-\left(\mathrm{Cl}^{-}+\mathrm{S}^{2-}\right)$ [Equation 2]. Goff (2000) proposed a variation of this equation based on the capacity of different salts to acidify urine and recommended DCAD $=\left(0.15 \mathrm{Ca}^{2+}+0.15 \mathrm{Mg}^{2+}+\mathrm{Na}^{+}+\mathrm{K}^{+}\right)-$ $\left(\mathrm{Cl}^{-}+0.25 \mathrm{~S}^{2-}+0.5 \mathrm{P}^{3-}\right)$ [Equation 3]. Following research of Spears et al. (1985), who estimated that the 
absorption of sulfur from the gastrointestinal tract was $60 \%$ of dietary intake, Tucker et al. (1991) suggested that $\mathrm{DCAD}=\left(0.38 \mathrm{Ca}^{2+}+0.3 \mathrm{Mg}^{2+}+\mathrm{Na}^{+}+\mathrm{K}^{+}\right)-\left(\mathrm{Cl}^{-}\right.$ $+0.6 \mathrm{~S}^{2-}+0.5 \mathrm{P}^{3-}$ ) [Equation 4]. One goal of the study was to determine, which, if any of these equations most accurately predicted risk of milk fever.

The optimal dietary concentration of calcium in prepartum diets is also contentious. Goff (2000) concluded that calcium concentration in prepartum diets had little influence on the incidence of milk fever when fed at levels above the daily requirements, approximately 30 $\mathrm{g}$ of calcium/d. Oetzel (2000) and Thilsing-Hansen et al. (2002) noted that the practice of feeding very low levels of calcium prepartum, $<20 \mathrm{~g} / \mathrm{d}$, is effective in controlling hypocalcemia. However, Oetzel (2000) recommended a daily intake of $150 \mathrm{~g}$ of calcium/d in the prepartum diet, a calcium concentration of between 1.1 and $1.5 \%$ of $\mathrm{DM}$, in conjunction with a dietary DCAD (based on Equation 1) of approximately $-15 \mathrm{mEq} / 100$ $\mathrm{g}$ of DM. However, this recommendation was not supported by his meta-analysis, which showed that the highest milk fever risk occurred with a dietary calcium concentration of 1.16\% (Oetzel, 1991). Lean et al. (2003) suggested a prepartum intake of $60 \mathrm{~g}$ of calcium/d based on the seminal studies of Boda and Cole (1954) and Ramberg et al. (1976, 1984).

To investigate and attempt to clarify these areas of contention, data from the meta-analysis of Oetzel (1991) were updated with relevant, subsequent trials and reanalyzed. Oetzel (1991) concluded that his results substantiated the DCAD theory of milk fever prevention and concluded that the role of calcium in milk fever was nonlinear; extremely low and extremely high concentrations reduced the relative risk of milk fever. It was concluded that sulfate and sodium were the dietary electrolytes most closely linked with milk fever and were more important than DCAD or calcium concentration. Enevoldsen (1993) expressed concern at the methods used by Oetzel (1991), including the sparseness of data in regard to the number of covariate patterns, and reanalyzed Oetzel's data. Enevoldsen (1993) similarly found that low dietary sulfur increased the risk of hypocalcemia, but disputed other conclusions of Oetzel (1991). In particular, calcium entered final models developed by Enevoldsen (1993) as a linear effect. Both Enevoldsen (1993) and Oetzel (1991) used fixed effects models for predicting outcomes, and it is now widely accepted that these models are vulnerable to overdispersion associated with clustering of effects in trials. Random effects models, for example logistic normal regression, are preferred for such analyses (Dohoo et al., 2003).

The aim of this study was to develop random effect, predictive models to test hypotheses arising from recent reviews using the much larger number of studies and improved statistical methods available since the metaanalyses of Oetzel (1991) and Enevlodsen (1993).

\section{MATERIALS AND METHODS}

The data set for this meta-analysis was developed using the original data set from Oetzel (1991) as published. Studies published since 1990 were added, as well as any studies originally excluded by Oetzel (1991), on the basis that cows were exposed to the transition diet for $<14 \mathrm{~d}$. Relevant papers were identified by computerized literature searches (CAB Abstracts, BA Abstracts, PubMed, Agricola, Medline, Biological Abstracts, Biosis Previews, Australian Bibliography of Agriculture and ScienceDirect), library searches of relevant journals, and a systematic review of citations in identified review papers. Contact was made with some workers in the field to identify studies that might have been missed through the literature review process.

In all, 48 English-language, published papers were reviewed. Of the papers that were assessed, only those that satisfied specific predetermined criteria were included in the analyses. These criteria included evidence 1) that the trial was randomized, 2) that the populations studied were pregnant dairy cows that calved during the trial period, and 3) that enough detail on dietary composition was provided to allow calculation of the DCAD of the transition diet without use of book values for mineral composition of feeds. Trials were ineligible for inclusion in the analysis 1 ) if there was insufficient evidence of randomization, 2) if the trial was confounded with supplementary treatments such as bovine somatotropin, 3) if the paper provided insufficient data on the variables being measured, or 4) if hypocalcemia was induced in the study animals by use of either feed restriction or calcium binding agents (such as NaEDTA given intravenously in cows or zeolites in feed). Length of exposure to the prepartum transition diet was determined for each trial that reported this variable. Breed classification was recorded, and lactation number was calculated using methods described by Oetzel (1991). The 4 variations of the DCAD equation detailed previously were calculated where possible in units of $\mathrm{mEq} /$ $100 \mathrm{~g}$ of DM and were tested in statistical models developed. The final data set was derived from 35 papers detailing 137 individual trials involving 2,545 observed calvings. Details of the trials investigated are presented in Appendix A.

This data set contained a large number of variables that were not consistently reported in each study. There were, however, essentially 3 different subsets of data that could be evaluated. These contained information on dietary concentrations of calcium, magnesium, phos- 
phorus, potassium, sodium, chloride, and sulfur and age; crude protein; or time exposed to prepartum diet. We used a standardized approach for data evaluation; our goal was to retain a large data set, but retain variables that demonstrated a consistent effect on milk fever in each of the different data sets.

\section{Statistical Analysis}

Initial investigation was conducted using graphical display of variables plotted against milk fever incidence using logistic regression with a fixed effect of trial. Milk fever incidence was assessed by logistic regression using Statistix 8 (Statistix, 2003). Following univariate analyses, a process of model building was undertaken using forward and backward stepping and model fitting. Variables with a $P<0.3$ in univariate analyses were allowed into later models for testing. This process was conducted for each of the different data sets. Fixed effect models were assessed on improvement in model fit using Hosmer-Lemeshow statistics, significance of variables entering, receiver-operator curves, and proportion of cases correctly predicted.

We used a systematic method of evaluating data univariately and subsequently with multivariate fixed and random effects models before using a subset of data that contained studies with detail of duration of exposure to the prepartum diet, but not including age or protein content of the diet. Investigation of variables in the different data subsets provided confidence that significant variables were not included in final models by chance; rather, these were very consistently significant in a large number of models developed with the different subsets of data. Final models were forward stepped and, interactions among variables and quadratic terms for included variables were sequentially included or excluded if not significant.

Following preliminary analysis, random effects models were used to evaluate these data (Egret, version 2.0.31, Cytel Software Corporation, Cambridge, MA). A random effects, logistic normal model was used based on the distribution of incidence of milk fever in trials, to develop final models, and interaction terms in the final models selected were then tested. Evidence of confounding was assessed from change in the coefficients when subsequent variables were entered. Biological plausibility of variables was also considered in the inclusion of variables that could have a quadratic response as well as any interactions between variables. The model for the response probability $\pi i$ is given by

$$
\operatorname{logit}(\pi i)=x \_i \beta+\sigma u i
$$

where $\sigma$ is a constant $>0$, and $u_{i} \stackrel{i \text { id }}{\sim} \mathrm{N}(0,1)$. Unlike the beta-binomial and logistic binomial models, the logistic
Table 1. Descriptive statistics of primary variables tested during model development

\begin{tabular}{lcclc}
\hline Variable & Trials & Mean & SEM & SD \\
\hline Cows, no. & 137 & 18.4 & 2.80 & 32.72 \\
Milk fever incidence & 137 & 0.21 & 0.021 & 0.245 \\
Days exposed to transition diet & 110 & 26 & 1.1 & 11.5 \\
Lactation number & 83 & 4 & 0.2 & 1.9 \\
CP, \% of DM & 115 & 14.5 & 0.29 & 3.15 \\
Ca, \% of DM & 131 & 1.02 & 0.045 & 0.518 \\
P, \% of DM & 127 & 0.42 & 0.020 & 0.227 \\
Mg, \% of DM & 116 & 0.27 & 0.010 & 0.111 \\
Na, \% of DM & 121 & 0.29 & 0.024 & 0.259 \\
K, \% of DM & 121 & 1.71 & 0.056 & 0.620 \\
Cl, \% of DM & 120 & 0.67 & 0.043 & 0.470 \\
S, \% of DM & 120 & 0.29 & 0.012 & 0.126 \\
DCAD 1, mEq/kg of DM & 129 & 19.1 & 1.93 & 21.94 \\
DCAD 2, mEq/kg of DM & 109 & 33.3 & 2.17 & 22.62 \\
DCAD 3, mEq/kg of DM & 107 & 40.1 & 2.07 & 21.44 \\
DCAD 4, mEq/kg of DM & 107 & 38.6 & 1.93 & 19.99 \\
\hline
\end{tabular}

normal model yields a marginal likelihood for which there exists no closed form (Egret, Cytel Software Corp.). Logistic normal models are appropriate to use in analyses where data are clustered within a variable, for example litter, family, or in this case herd. In such situations, the effect of herd is included in the logistic normal model as a random effect.

The models were assessed for fit by examining graphs that showed residuals for each trial in the data set. Further examination of the final models was conducted by using linear regression to evaluate the predicted milk fever incidence derived from models against the observed milk fever incidence from the 37 trials excluded because of missing values from the original data used to generate the models. The missing values in these trials were replaced with mean values from the analyzed data. Residual plots from these models were evaluated.

\section{RESULTS}

Descriptive statistics for the primary variables that were tested during the development of the final models are shown in Table 1. Initial exploration of the data using graphs of variables studied plotted against milk fever incidence did not reveal any obvious cut points for any of the variables investigated. Therefore, all variables were treated as continuous to minimize the loss of information. Figure 1, for example, shows an essentially linear association between DCAD and milk fever risk.

The final data set did not contain age, as this was reported in too few studies; only 87 studies accurately recorded the age or lactation number of the trial cows, and many of these had other missing data. Further, the data subset used in final model development did 


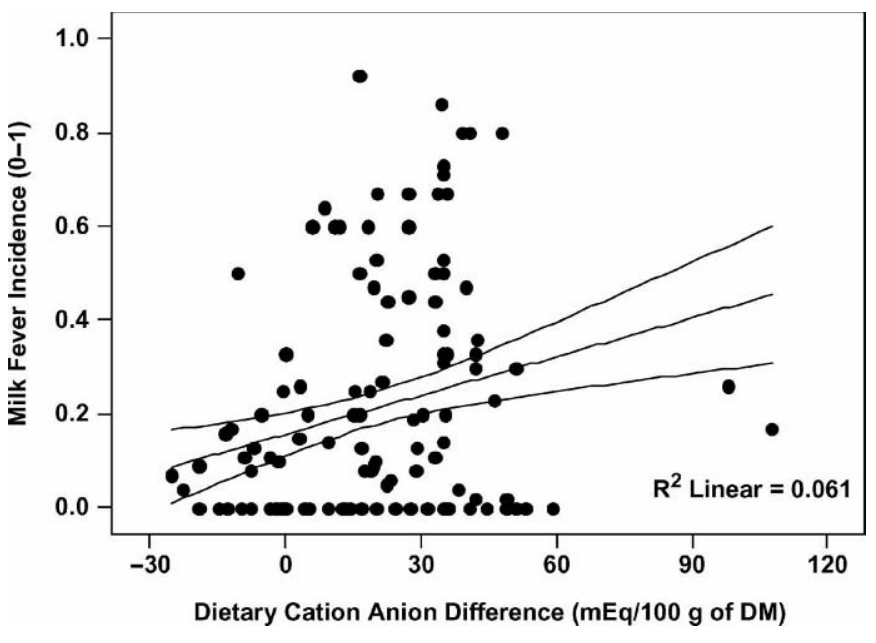

Figure 1. Unweighted linear regression for milk fever incidence in trials against dietary cation anion difference $(\mathrm{mEq} / 100 \mathrm{~g}$ of $\mathrm{DM})$.

not contain crude protein content of the diet, as this was not consistently significant in preliminary models evaluated. Neither age nor protein was a significant confounder of the major effects identified in other models. Consequently, the estimates of effects identified in the final models should not be greatly altered with inclusion of information on age or protein content of diets. The data set did contain duration of exposure to the prepartum diet. This factor was both consistently significant and confounded coefficients for calcium and magnesium by altering these by $>25 \%$. Many fixed effects models adequately predicted group inclusions, but 4 models considered for final evaluation had superior fits to the data, as indicated by higher Hosmer-Lemeshow $P$ values (Table 2 ). These models were further evaluated and modified by fitting random effects models to the originally defined variables.

Coefficients for significant variables were relatively stable across a large number of models, including duration of exposure to prepartum diets, which substantially influenced regression coefficients for calcium, magnesium, and phosphorus, but also resulted in a loss of trials, because it was reported in only 110 trials. Two random effects models (Tables 3 and 4) were developed that had comparable predictive values and fit (Table 5 ). For both of these models, there was considerable evidence of overdispersion of data as indicated by a marked decrease in model deviance when random effects models were fitted. There was also a large amount of subject heterogeneity in data as shown by the large estimates of the variance component, $\hat{\sigma}^{2}$, relative to the standard error. Both these observations support use of random effects models to evaluate these data.

The logit transformations (LT 1 and LT 2) of logistic regression equations for predicting the incidence of milk fever for the Holstein-Friesian breed from prepartum dietary nutrients as calculated using the random effect model are:

$$
\text { LT } 1=-5.76+5.48(\mathrm{Ca})-5.05(\mathrm{Mg})+1.85(\mathrm{P})+0.02
$$$$
\left(\text { DCAD 1) }-2.03\left(\mathrm{Ca}^{2}\right)+0.03\right. \text { (Exposure) }
$$

LT $2=-5.17+5.74(\mathrm{Ca})-8.66(\mathrm{Mg})+2.30(\mathrm{P})+0.78$

$$
(\mathrm{K})-3.48(\mathrm{~S})-2.16\left(\mathrm{Ca}^{2}\right)+0.04 \text { (Exposure) }
$$

The reference breed in each of the models is the Holstein-Friesian breed. The adjustments for the coefficient in the logit models for breeds other than HolsteinFriesian are as follows: for the Jersey breed, 0.86 and 0.66 for Models 1 and 2 respectively, and for Norwegian and Swedish Red and White breeds, 1.49 for Model 1. Only the Jersey breed differed significantly from the Holstein-Friesian breed in risk of milk fever in Equation $1(P<0.05)$ and approached significance $P=0.09$ in Equation 2. Risk of milk fever in cows of mixed breed or where no breed was recorded compared with the Holstein-Friesian breed did not approach significance in either model $(P>0.2)$.

Predicted incidence of milk fever can be calculated from each of the logit transformations using the following equation:

$$
\text { Milk fever } \%=e^{\mathrm{LT}} /\left(1+e^{\mathrm{LT}}\right) \times 100 \text {. }
$$

The response to dietary calcium concentration, within the range of analyzed data, for Model 1 is presented in Figure 2. This was calculated using breed = Holstein-Friesian, magnesium $=0.4 \%$, phosphorus $=$ $0.4 \%$, potassium $=1.6 \%$, sodium $=0.3 \%$, sulfur $=0.4 \%$, chlorine $=1.8 \%$, exposure $=14 \mathrm{~d}$, and DCAD $1=-21$ $\mathrm{mEq} / 100 \mathrm{~g}$ of DM. These factors were levels for those variables at which risk of milk fever was low.

\section{Model Validation}

The final models were validated using milk fever incidence reported in 51 trials that had missing values. Missing values were replaced with mean values, as shown in Table 1, from trials included in the final model development. For example, missing values for calcium, sulfur, or chlorine were replaced with $1.02,0.29$, and $0.67 \%$ of DM, respectively. Of the 51 trials, 34 trials had one missing variable, 3 trials had 2 missing variables, 2 trials had 4 missing variables, 8 trials had 5 missing variables, and 4 trials had 7 missing variables. The 14 trials with $>4$ missing variables were excluded from the analysis, leaving 37 trials for analysis. The 2 models were fitted to the data, and predicted incidences of milk 
Table 2. The 4 fixed effect models (coefficients, $P$ values, and Hosmer-Lemeshow statistics) used for final fitting to the random effect models

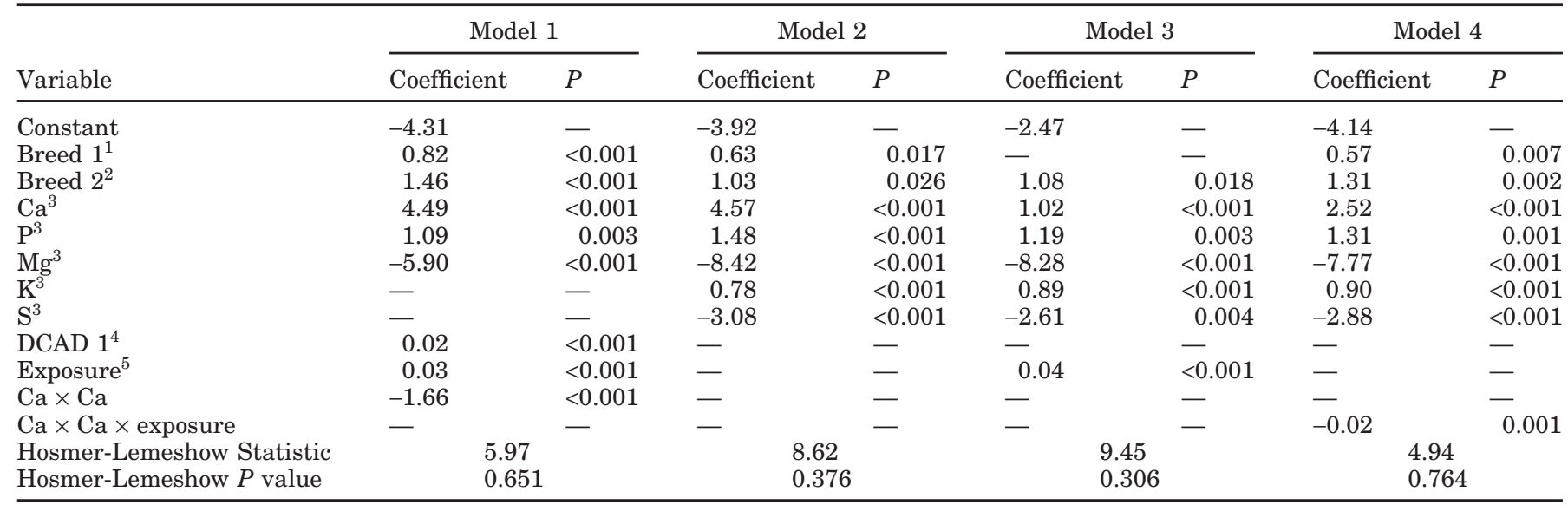

${ }^{1}$ Breed 1 = Jersey (Holstein-Friesian used as the reference breed).

${ }^{2}$ Breed 2 = Norwegian and Swedish Red and White (Holstein-Friesian used as the reference breed).

${ }^{3} \mathrm{Ca}, \mathrm{Mg}, \mathrm{P}, \mathrm{K}$, and $\mathrm{S}$ are expressed as percentages of DM.

${ }^{4} \mathrm{DCAD} 1=(\mathrm{Na}+\mathrm{K})-(\mathrm{Cl}+\mathrm{S})$ in $\mathrm{meq} / 100 \mathrm{~g}$ of $\mathrm{DM}$.

${ }^{5}$ Exposure is mean time (in days) that cows in the study were exposed to the precalving transition diet.

fever were retained and evaluated against the observed incidence for each trial. Linear regression weighted for trial size was used to assess the fit of models (Table 6). Both models provided estimated incidence rates that produced significant linear regression models; intercepts approximated zero, and slopes approached unity. Both models had standardized residuals that, when fitted against observed values, demonstrated appropriate model selection.

\section{DISCUSSION}

A total of 35 papers detailing 137 individual trials involving 2,545 observed calvings was used in the anal- ysis with the resultant data set substantially larger than the original data set developed by Oetzel (1991), which contained 1,165 observed calvings across 75 individual trials. The larger data set available might have reduced problems of instability in models identified by Enevoldsen (1993), as coefficients for most variables were relatively stable across a large number of models. Because of missing data, data analysis was a lengthy process involving screening different models developed using different subsets of studies.

The lack of data on dietary composition reported in studies, particularly with regard to dietary protein and carbohydrate fractions, and feed intake limited testing of hypotheses relating to these variables. In contrast

Table 3. Random effects, logistic normal regression Model 1 for the prediction of the incidence of milk fever. A total of 87 trials were used in this analysis

\begin{tabular}{llllcl}
\hline $\begin{array}{l}\text { Predictor } \\
\text { variable }\end{array}$ & Coefficient & SE & $P$ value & Odds ratio & $\begin{array}{l}95 \% \text { Confidence } \\
\text { interval }\end{array}$ \\
\hline Constant & -5.76 & 1.028 & 0.001 & 0.003 & $0.001-0.024$ \\
Breed $1^{1}$ & 0.86 & 0.382 & 0.024 & 2.374 & $1.122-5.023$ \\
Breed $2^{2}$ & 1.49 & 0.824 & 0.071 & 4.424 & $0.880-22.235$ \\
$\mathrm{Ca}^{3}$ & 5.48 & 1.729 & 0.013 & 239.362 & $8.082-7,089.244$ \\
$\mathrm{Mg}^{3}$ & -5.05 & 1.618 & 0.002 & 0.006 & $0.001-0.152$ \\
$\mathrm{P}^{3}$ & 1.85 & 0.716 & 0.010 & 6.376 & $1.566-25.958$ \\
$\mathrm{DCAD} \mathrm{1}$ & 0.02 & 0.007 & 0.040 & 1.015 & $1.001-1.030$ \\
$\mathrm{Ca} \times \mathrm{Ca}$ & -2.03 & 0.819 & 0.013 & 0.131 & $0.026-0.654$ \\
Exposure & 0.03 & 0.014 & 0.030 & 1.030 & - \\
Trial & -0.01 & 0.001 & 0.369 & - & - \\
Variance $(\sigma)$ & 1.33 & 0.357 & - & - & - \\
\hline
\end{tabular}

${ }^{1}$ Breed 1 = Jersey (Holstein-Friesian used as the reference breed).

${ }^{2}$ Breed 2 = Norwegian and Swedish Red and White (Holstein-Friesian used as the reference breed).

${ }^{3} \mathrm{Ca}, \mathrm{Mg}$, and $\mathrm{P}$ are expressed as percentages of $\mathrm{DM}$.

${ }^{4} \mathrm{DCAD} 1=(\mathrm{Na}+\mathrm{K})-(\mathrm{Cl}+\mathrm{S})$ in $\mathrm{meq} / 100 \mathrm{~g}$ of $\mathrm{DM}$.

${ }^{5}$ Exposure is mean time (in days) that cows in the study were exposed to the precalving transition diet. 
Table 4. Random effects, logistic normal regression Model 2 for the prediction of the incidence of milk fever. A total of 87 trials were used in this analysis.

\begin{tabular}{|c|c|c|c|c|c|}
\hline $\begin{array}{l}\text { Predictor } \\
\text { variable }\end{array}$ & Coefficient & $\mathrm{SE}$ & $P$ value & Odds ratio & $\begin{array}{l}95 \% \text { Confidence } \\
\text { interval }\end{array}$ \\
\hline Constant & -5.17 & 1.048 & 0.001 & 0.006 & $0.001-0.045$ \\
\hline Breed $1^{1}$ & 0.66 & 0.383 & 0.087 & 1.927 & $0.910-4.084$ \\
\hline $\mathrm{Ca}^{2}$ & 5.74 & 1.788 & 0.001 & 309.576 & $9.306-10,298.030$ \\
\hline $\mathrm{Mg}^{2}$ & -8.66 & 2.007 & 0.001 & 0.001 & $0.001-0.009$ \\
\hline $\mathrm{P}^{2}$ & 2.29 & 0.717 & 0.001 & 9.872 & $2.423-40.227$ \\
\hline $\mathrm{K}^{2}$ & 0.78 & 0.313 & 0.013 & 2.185 & $1.183-4.036$ \\
\hline $\mathrm{S}^{2}$ & -3.48 & 1.513 & 0.022 & 0.031 & $0.002-0.598$ \\
\hline $\mathrm{Ca} \times \mathrm{Ca}$ & -2.16 & 0.844 & 0.010 & 0.115 & $0.022-0.601$ \\
\hline Exposure $^{3}$ & 0.04 & 0.014 & 0.003 & 1.042 & $1.014-1.071$ \\
\hline Trial & -0.003 & 0.005 & 0.524 & - & - \\
\hline Variance $(\sigma)$ & 1.24 & 0.350 & - & - & - \\
\hline
\end{tabular}

to the model developed by Oetzel (1991), dietary crude protein was not included in final models. It did, however, approach significance in a number of preliminary fixed effects models $(0.1<P<0.2)$. The lack of information that could be obtained on age of cows also lead to an inability to include age in final models developed. There is good evidence that increasing age increases risk of milk fever as a result of decreased intestinal calcium absorption and responsiveness to hypocalcemia (Hansard et al., 1954; Horst et al., 1978, 1990), reduced bone turnover (Parfitt, 1984), and decreased bone responsiveness to parathyroid hormone and vitamin D (Goff et al., 1991a). This lack of data is a limitation to the models presented, which would likely be improved by inclusion of age data. Nonetheless, meta-analysis of large data sets is a powerful tool for evaluating whether physiological effects, such as those of anionic DCAD treatments or efficiency of absorption of minerals, identified in smaller, more tightly controlled studies, have an effect on disease risk.

Two final models with good fit and good predictive ability are presented in this paper. The final models were developed using random effects models. This approach was supported by the observed decrease in variance in the random vs. fixed effects models and in the high estimates of variance relative to the standard deviations found in the final models. There are, consequently, several strong reasons for conducting this meta-analysis, specifically, the greater availability of

Table 5. Linear regression of predicted milk fever incidence against observed cases for the 84 trials used to develop predictive models

\begin{tabular}{lllll}
\hline Model & Constant & Coefficient & $\mathrm{R}^{2}$ & $P$ \\
\hline 1 & -0.024 & 1.051 & 0.398 & 0.001 \\
2 & 0.009 & 0.999 & 0.395 & 0.001 \\
\hline
\end{tabular}

data than available for Oetzel (1991), the use of random effects models that are required proper evaluation and presentation of these data, and the examination of new hypotheses, especially the value of different DCAD equations recently proposed.

The fit of random effects models is difficult to assess (Dohoo et al., 2003). In this case, however, expected incidence data produced by the models could be fitted against the observed incidence both from data used to produce the models and in the independent data provided in trials with missing data. The linear regression models (Tables 5 and 6) showed good fits, providing support for the final models developed. Although effects of age on risk of milk fever could not be included in the final models, this effect and the effect of breed of cow that was included in the model, are not immediately available to manipulation by farmers or their advisers. Consequently, the approximately $40 \%$ variance ex-

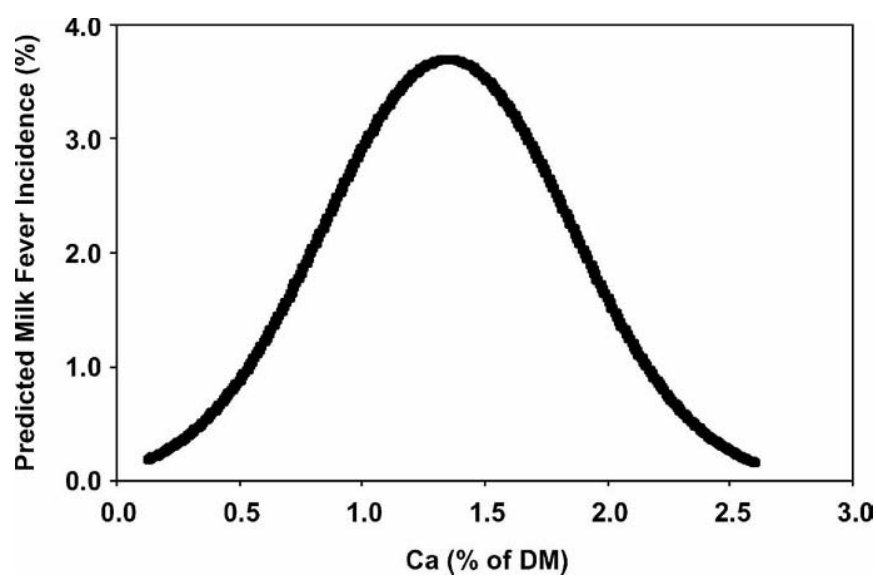

Figure 2. Milk fever incidence in response to varying dietary calcium concentrations as predicted by Model 1 . 
Table 6. Weighted linear regression of predicted milk fever incidence against observed cases for trials used to validate the models

\begin{tabular}{lllll}
\hline Model & Constant & Coefficient & $\mathrm{R}^{2}$ & $P$ \\
\hline 1 & -0.05 & 1.103 & 0.31 & $<0.001$ \\
2 & -0.03 & 0.960 & 0.28 & $<0.001$ \\
\hline
\end{tabular}

plained by the models developed is very satisfactory given that the outcome of interest, milk fever was not absolutely consistently nor comprehensively defined for cows in the studies.

The decision to retain 2 models for presentation reflected strong evidence in univariate assessment that a low DCAD (assessed by Equation 1) was associated with a low incidence of milk fever. Exploratory analysis indicated that this was, clearly, the best of the DCAD models for explaining milk fever incidence. During the process of model development, DCAD Equations 2, 3, and 4 did not approach significance in either the fixed or random effect models. Milk fever risk declined linearly with DCAD assessed by Equation 1 (Figure 1), in contrast with the nonlinear response of urinary $\mathrm{pH}$ to lower DCAD (McNeill et al., 2002). In Model 1, an increase in DCAD in the precalving diet from -25 to $+25 \mathrm{mEq} /$ $100 \mathrm{~g}$ increases risk of milk fever by $110 \%$. There was no additional gain in model predictions or fit from the inclusion of dietary concentrations of multivalent ions other than sulfur or from the inclusion of absorption coefficients in DCAD equations. The inclusion of calcium, magnesium, or phosphorus in DCAD equations to predict milk fever risk must, therefore, be questioned. In both models, the second-order effect of calcium, contrasted with a linear effect predicted by DCAD Equations 2,3 , and 4 . Increasing dietary concentrations of magnesium reduce milk fever risk markedly, again in contrast to the predicted effect of the DCAD Equations 2, 3 and 4. Similarly, increasing phosphorus concentrations increase milk fever risk, whereas a protective role is proposed in DCAD Equations 2, 3 and 4. These observations reinforce the difference between models designed to predict DCAD with those designed to predict milk fever. Strategies designed to solely manipulate DCAD to alter acid-base status are not necessarily those best designed to minimize milk fever risk.

The final models are similar in modeling risk of milk fever but differ in a critical aspect, specifically, the roles of chloride and sodium. Neither sodium nor chloride was included in Model 2, but both were present in Model 1 through inclusion of DCAD (Equation 1). This is surprising, as there is a substantial body of evidence, both experimental and from field observations, to support an important role of these ions in the pathogenesis of milk fever. High dietary sodium content is a risk factor for milk fever (Dishington, 1975; Goff and Horst, 1997;
Goff et al., 1991a; Oetzel, 1991), and there is also anecdotal evidence that sodium bicarbonate fed before calving increases milk fever incidence. Conversely, increasing dietary chloride intake reduces the risk of milk fever (Oetzel et al., 1988; Gaynor et al., 1989; Goff and Horst, 1998; Goff et al., 1991a; Tucker et al., 1991). The lack of chloride or sodium in Model 2 may reflect a lack of reporting of chloride or sodium values for many early trials originally analyzed by Oetzel (1991). These concentrations were often calculated from book values by Oetzel (1991) and were subsequently used in this study. There is a greater coefficient of variation in feed chloride concentrations than in feed sulfur concentrations. The effect of nondifferential errors in measurement is to drive hypotheses toward the null, potentially resulting in lack of significance for important factors. Consequently, we suggest that inclusion of chloride and sodium through DCAD in Model 1 is preferred over the omission of these in Model 2.

Potassium and sulfur both had a highly significant and substantial effect on milk fever incidence. Higher potassium concentrations greatly increased milk fever incidence, and higher sulfur concentrations strongly and linearly reduced milk fever risk. These observations are consistent with the proposed effects of strong ions on milk fever incidence mediated through the DCAD (Block, 1984; Goff et al., 1989; Tucker et al., 1991; Goff and Horst, 1997; Constable, 1999; Goff, 2000). It is possible also that potassium may have an effect on milk fever mediated by a negative effect on magnesium absorption (Suttle and Field, 1967); however, statistical interactions between potassium and magnesium concentrations were not significant, providing no support for this interaction playing a critical role in the pathogenesis of milk fever. The role of sulfur in prevention of milk fever has been contentious. The effect of sulfur on milk fever risk was linear in both Models 1 and 2, suggesting the possibility of an effect not related to DCAD; however, such mechanisms are yet to be demonstrated. Ramberg et al. (1996) suggested several mechanisms by which sulfur could reduce the risk of milk fever, including an acidogenic effect, if gastrointestinal absorption of $\mathrm{SO}_{4}{ }^{2-}$ was preferential over $\mathrm{Mg}^{2+}$, and a possible laxative effect of magnesium sulfate that might increase bicarbonate losses in the feces. It will be difficult to determine whether any such physiological actions of sulfur, apart from a role in DCAD, influence risk of milk fever independently of the role in DCAD.

The second-order effect of calcium present in both models strongly supports the concept that either low dietary calcium percentage (Boda and Cole, 1954; Goings et al., 1974; Wiggers et al., 1975) or high dietary calcium percentage (Lomba et al., 1978; Oetzel et al., 
1988) fed prepartum reduces milk fever risk. The effect of low calcium diets on calcium homeostasis is well established and has been reviewed in depth (Goings et al., 1974; Green et al., 1981). Goff and Horst (1997), however, proposed that observed benefits of lowering dietary calcium prepartum to approximately $50 \mathrm{~g} / \mathrm{d}$ in preventing milk fever were, in part, the result of a reduction of dietary potassium rather than a stimulatory effect of low dietary calcium on calcium homeostasis. Those researchers cited evidence that dietary calcium needed to be restricted to $<20 \mathrm{~g} / \mathrm{d}$ to sufficiently stimulate the calcium homeostatic mechanism that prevents milk fever. It was also found that when the effects of calcium were separated from the effects of the strong dietary cations, calcium consumption above the dietary requirements of the cow had little effect on the incidence of milk fever. These postulates are not supported by this study, which shows that the effects of calcium and potassium were independent and that the effect of calcium content of the diet in the final models on milk fever risk is quadratic. The effect of raising dietary calcium concentration from 0.5 to $0.6 \%$ while maintaining all other variables, as predicted by Model 1, is to increase the risk of milk fever by approximately $37 \%$. An increase in calcium concentration from 0.5 to $1.0 \%$ in the precalving diet would increase the risk by $327 \%$.

The process by which very high dietary calcium concentrations prepartum may reduce milk fever risk is unclear. It has been suggested that higher concentrations of calcium increase uptake of calcium by passive absorption and may counteract the depletion of calcium associated with low DCAD diets (Lean et al., 2003). The hypercalciuric effect of low DCAD diets (Vagnoni and Oetzel, 1998; van Mosel et al., 1993) may lower readily available bone calcium and, hence, bone calcium reserves available for mobilization after calving. Feeding higher dietary calcium concentrations prepartum may prevent this. This hypercalcuric effect may be exacerbated with increased duration of exposure to a low $\mathrm{DCAD}$ diet prepartum. Longer exposure to a prepartum transition diet would, therefore, increase the incidence of milk fever as predicted in both models. Although increased urinary calcium loss on low DCAD diets has been demonstrated (van Mosel et al., 1993; Vagnoni and Oetzel, 1998), an effect of duration of exposure to the low DCAD diet on milk fever risk has not been established in trial work. Exposure was a consistently significant variable in models developed with this variable and acted to substantially modify coefficients for calcium and magnesium. Increasing exposure to the diet before calving from 20 to $30 \mathrm{~d}$ increased risk of milk fever by $42 \%$. Therefore, it was necessary to include this variable in models, in contrast to those previously developed by Oetzel (1991) and Enevoldsen (1993). Fur- ther, an interaction term between the quadratic effect of calcium and exposure was significant in many models (e.g., Table 2$)$ and approached significance $(P<0.15)$, but was not included in the final models. This term suggested that short exposures to higher concentrations, $>1.5 \%$, of calcium increase risk of milk fever, whereas longer term exposures to high concentrations of calcium decrease risk. Given, that there are fewer studies that fed $>1.5 \%$ calcium in the prepartum diet than fed $<0.5 \%$, we consider that the observed quadratic response in milk fever risk to calcium concentrations should be tested in experimental protocols that also examine length of exposure to the prepartum diet.

The regression equations calculated also showed a very strong association between higher concentrations of magnesium in the diet and a lower incidence of milk fever. For example, an increase in magnesium concentration from 0.3 to $0.4 \%$ of $\mathrm{DM}$, while maintaining the other variables, would result in an approximate $62 \%$ decrease in milk fever risk. There are sound physiological bases for a protective role of magnesium in the pathogeneses of milk fever. Apart from the role of magnesium in the synthesis of proteins, RNA, and DNA, many enzymes such as those involved in the dephosphorylation of ATP and kinases are magnesium dependent (Martens and Schweigel, 2000). Magnesium is critical in the release of parathyroid hormone and in the synthesis of 1,25-dihydroxycholecalciferol. In hypomagnesaemic states, kidney and bone are less responsive to parathyroid hormone as a result of the reduced synthesis of the intermediary cellular messengers adenylate cyclase and phospholipase C (Sampson et al., 1983; Goff, 2000). Metabolic acidosis, such as that induced by a low DCAD prepartum diet, may also increase renal excretion of magnesium (Horst and Jorgensen, 1974; Fredeen et al., 1988). Experimental evidence supports a key role for magnesium in calcium homeostasis. Wang and Beede (1992) found that nonpregnant, nonlactating cows fed a diet high in magnesium had lower renal calcium excretion than those fed a diet low in magnesium. Contreras et al. (1982) demonstrated that hypomagnesemic cows were less able to respond to an acute drop in plasma calcium secondary to intravenous administration of NaEDTA than were normo-magnesemic cows, and van de Braak et al. (1987b) also found that calcium mobilization rates at parturition were slower when cows were fed a prepartum diet deficient in magnesium.

Phosphorus was also a significant predictor of milk fever, as increasing phosphorus concentrations increased milk fever risk. For example, increasing the phosphorus concentration from 0.3 to $0.4 \%$ in the precalving diet would increase risk of milk fever by $18 \%$. There is a sound physiological basis for this relation- 
ship. Although phosphorous concentrations are not as tightly regulated as calcium, both are closely related to plasma $\mathrm{PO}_{4}$ concentrations regulated directly by 1,25 $(\mathrm{OH})$ vitamin D3 and indirectly by the parathyroid hormone/calcium negative feedback loop (Goff, 1999). However, in rats, hyperphosphatemia can inhibit the activity of renal 25-hydroxyvitamin D 1 alpha-hydroxylase despite increased synthesis of parathyroid hormone thereby reducing production of $1,25 \mathrm{OHD}_{3}$ sufficiently to cause hypocalcemia (Tallon et al., 1996; Silver et al., 1999; Masuyama et al., 2000). In cattle, there is evidence that a prepartum diet high in phosphorus can have a negative impact on calcium homeostasis possibly by the same pathways (Julien et al., 1977; Kichura et al., 1982; Barton et al., 1987).

The increased risk of milk fever for Jersey and Norwegian and Swedish Red and White cows compared with Holstein-Friesian cows was not surprising, as these risks are well recognized. Many of the studies involving Norwegian and Swedish Red and White cows were older, and breeding programs to select for lower disease risks may alter the magnitude of this risk.

\section{CONCLUSIONS}

Models predicting milk fever risk were developed and successfully validated. The models generated in this analysis provide support for the DCAD theory of milk fever pathogenesis. However, the study highlights the difference between developing equations to predict DCAD accurately, compared with predicting milk fever risk. For example magnesium, which acts to increase DCAD in some proposed equations, had a profound effect in reducing risk of milk fever. The strong mono and divalent ions, potassium and sulfur, either singly or in DCAD, predicted milk fever risk. Both final models predicted a low incidence of milk fever with low $(<0.5 \%)$ dietary calcium levels. The practice of feeding prepartum diets high in calcium (1.1 to 1.5\%) cannot be recommended at present, as this dietary concentration range equated to peak milk fever risk in both final models and all 4 preliminary models. Further, some satisfactory statistical models developed (not shown) contained a linear effect of calcium, and data were relatively sparse for higher calcium concentrations. There is a need for more research on the use of high calcium diets to prevent milk fever. High magnesium concentrations in the prepartum diet appear to be a critical determinant to lower milk fever incidence. Critical assessment and control of the dietary macro minerals included in the models, and not only DCAD of the prepartum diet, is essential in the prevention of milk fever. Despite the statistical equivalence of Models 1 and 2, the lack of inclusion of sodium and chloride in Model 2 seems to be contrary to a large body of evidence. Consequently, we propose that Model 1, which is also the more parsimonious statistical model, is the best model currently available for predicting milk fever incidence in dairy cows.

\section{ACKNOWLEDGMENT}

We appreciate the assistance of Ahmad Rabiee in preparation of the document.

\section{REFERENCES}

Barton, B. A., N. A. Jorgensen, and H. F. DeLuca. 1987. Impact of prepartum dietary phosphorus intake on calcium homeostasis at parturition. J. Dairy Sci. 70:1186-1191.

Block, E. 1984. Manipulating dietary anions and cations for prepartum dairy cows to reduce incidence of milk fever. J. Dairy Sci. 67:2939-2948.

Boda, J. M., and H. H. Cole. 1954. The influence of dietary calcium and phosphorus on the incidence of milk fever. J. Dairy Sci. 37:360-372.

Constable, P. D. 1999. Clinical assessment of acid-base status: Strong ion difference theory. Vet. Clin. North Am. Food Anim. Pract. 15:447-471.

Contreras, P. A., R. Manston, and B. F. Sansom. 1982. Calcium homeostasis in hypomagnesaemic cattle. Res. Vet. Sci. 33:10-16.

Dishington, I. W. 1975. Prevention of milk fever (hypocalcaemia paresis puerperalis) by dietary salt supplements. Acta Vet. Scand. 16:503-512.

Dohoo, I., W. Martin, and H. Stryhn. 2003. Veterinary Epidemiologic Research. AVC Inc., Charlottetown, Canada.

Ender, F., I. W. Dishington, and A. Helgebostad. 1962. Parturient paresis and related forms of hypocalcaemic disorders induced experimentally in dairy cows. Acta Vet. Scand. 3(Suppl 1):5-52.

Enevoldsen, C. 1993. Nutritional risk factors for milk fever in dairy cattle: Meta-analysis revisited. Acta Vet. Scand. Suppl. 89:131-134.

Fredeen, A. H., E. J. DePeters, and R. L. Baldwin. 1988. Characterization of acid-base disturbances and the effects of calcium and phosphorus balances of dietary fixed ions in pregnant or lactating does. J. Anim. Sci. 66:159-173.

Gaynor, P. J., F. J. Mueller, J. K. Miller, N. Ramsey, J. P. Goff, and R. L. Horst. 1989. Parturient hypocalcemia in Jersey cows fed alfalfa haylage-based diets with different cation to anion ratios. J. Dairy Sci. 72:2525-2531.

Goff, J. P. 1999. Treatment of calcium, phosphorus and magnesium balance disorders. Vet. Clin. North Am. Food Anim. Pract. 15:619-639.

Goff, J. P. 2000. Pathophysiology of calcium and phosphorus disorders. Vet. Clin. North Am. Food Anim. Pract. 16:319-337.

Goff, J. P., and R. L. Horst. 1997. Effects of the addition of potassium or sodium but not calcium to prepartum rations on milk fever in dairy cows. J. Dairy Sci. 80:176-186.

Goff, J. P., and R. L. Horst. 1998. Use of hydrochloric acid as a source of anions for prevention of milk fever. J. Dairy Sci. 81:2874-2880.

Goff, J. P., R. L. Horst, F. J. Mueller, J. K. Miller, G. A. Kiess, and H. H. Dowlen. 1991a. Addition of chloride to a prepartal diet high in cations increases 1,25-dihydroxyvitamin D response to hypocalcemia preventing milk fever. J. Dairy Sci. 74:3863-3871.

Goff, J. P., T. A. Reinhardt, and R. L. Horst. 1989. Recurring hypocalcemia of bovine parturient paresis is associated with the failure to produce 1,25 dihydroxyvitamin D. J. Endocrinol. 125:49-53.

Goings, R. L., N. L. Jacobson, D. C. Beitz, E. T. Littledike, and K. D. Wiggers. 1974. Prevention of parturient paresis by a prepartum calcium deficient diet. J. Dairy Sci. 57:1184-1188.

Green, H. B., R. L. Horst, D. C. Beitz, and E. T. Littledike. 1981. Vitamin D metabolites in plasma of cows fed a prepartum lowcalcium diet for prevention of parturient hypocalcemia. J. Dairy Sci. 64:217-226. 
Hansard, S. L., C. L. Comar, and M. P. Plumlee. 1954. The effects of age upon calcium utilization and maintenance requirements in the bovine. J. Anim. Sci. 13:25-36.

Horst, R. L., H. F. DeLuca, and N. A. Jorgensen. 1978. The effect of age on calcium absorption and accumulation of 1,25-dihydroxyvitamin D3 in intestinal mucosa of rats. Metab. Bone Dis. Relat. Res. 1:29-33.

Horst, R. L., J. P. Goff, and T. A. Reinhardt. 1990. Advancing age results in reduction of intestinal and bone 1,25-dihydroxyvitamin D receptor. J. Endocrinol. 126:1053-1057.

Horst, R. L., J. P. Goff, T. A. Reinhardt, and D. R. Buxton. 1997. Strategies for preventing milk fever in dairy cattle. J. Dairy Sci. 80:1269-1280.

Horst, R. L., and N. A. Jorgensen. 1974. Effect of ammonium chloride on nitrogen and mineral balance in lactating and non-lactating goats. J. Dairy Sci. 57:683-688.

Julien, W. E., H. R. Conrad, J. W. Hibbs, and W. L. Crist. 1977. Milk fever in dairy cows. viii. Effect of injected vitamin D3 and calcium and phosphorus intake on incidence. J. Dairy Sci. 60:431-436.

Kichura, T. S., R. L. Horst, D. C. Beitz, and E. T. Littledike. 1982. Relationships between prepartal dietary calcium and phosphorus, vitamin $\mathrm{D}$ metabolism, and parturient paresis in dairy cows. J. Nutr. 112:480-487.

Lean, I. J., P. J. DeGaris, L. K. Wade, and Z. K. Rajczyk. 2003. Transition management of dairy cows. Pages 221-248 in 2003 Australian \& New Zealand Combined Dairy Vet. Conf., Taupo, New Zealand. Foundation for Continuing Education of the New Zealand Veterinary Association, Palmerston North, New Zealand.

Lomba, F., G. Chauvaux, E. Teller, L. Lengeis, and V. Bienfet. 1978. Calcium digestibility in cows as influenced by the excess of alkaline ions over stable acid ions in their diets. Br. J. Nutr. 39:425-429.

Martens, H., and M. Schweigel. 2000. Pathophysiology of grass tetany and other hypomagnesemias. Vet. Clin. North Am. Food Anim. Pract. 16:339-368.

Masuyama, R., Y. Kajita, J. Odachi, M. Uehara, T. Shigematsu, K. Suzuki, and S. Goto. 2000. Chronic phosphorus supplementation decreases the expression of renal PTH/PTHrp receptor mRNA in rats. J. Nutr. 112:480-487.

McNeill, D. M., J. R. Roche, B. P. McLachlan, and C. R. Stockdale. 2002. Nutritional strategies for the prevention of hypocalcaemia at calving for dairy cows in pasture-based systems. Aust. J. Agric. Res. 53:755-770.

Oetzel, G. R. 1991. Meta-analysis of nutritional risk factors for milk fever in dairy cattle. J. Dairy Sci. 74:3900-3912.

Oetzel, G. R. 2000. Management of dry cows for the prevention of milk fever and other mineral disorders. Vet. Clin. North Am. Food Anim. Pract. 16:369-386.

Oetzel, G. R., J. D. Olson, D. R. Curtis, and M. J. Fetteman. 1988. Ammonium chloride and ammonium sulfate for prevention of parturient paresis in dairy cows. J. Dairy Sci. 71:3302-3309.

Parfitt, A. M. 1984. The cellular basis of bone remodeling: The quantum concept reexamined in the light of recent advances in the cell biology of bone. Calcif. Tissue Int. 36(Suppl. 1):37-45.
Ramberg, C. F., J. D. Ferguson, and D. E. Galligan. 1996. Metabolic basis of the cation-anion difference concept. Univ. Pennsylvania Annu. Vet. Conf.: Feeding and Managing Transition Cows. Univ. Pennsylvania, PA.

Ramberg, C. F., E. K. Johnson, R. D. Fargo, and D. S. Kronfeld. 1984. Calcium homeostasis in cows with special reference to parturient hypocalcemia. Am. J. Physiol. 246:R689-R704.

Ramberg, C. F., G. P. Mayer, D. S. Kronfeld, and J. T. Potts. 1976. Dietary calcium, calcium kinetics and plasma parathyroid hormone concentration in cows. J. Nutr. 106:671-679.

Sampson, B. F., R. Manston, and M. J. Vagg. 1983. Magnesium and milk fever. Vet. Rec. 112:447-449.

Silver, J., C. Yalcindag, A. Sela-Brown, and T. Naveh-Many. 1999. Regulation of the parathyroid hormone gene by vitamin $\mathrm{D}$, calcium and phosphate. Kidney Int. 56:2-7.

Spears, J. W., J. C. Burns, and P. A. Hatch. 1985. Sulphur fertilization of cool season grasses and effect on utilization of minerals, nitrogen and fiber by steers. J. Dairy Sci. 68:347-355.

Statistix. Version 8.0. 2003. Analytical Software. Statistix, Tallahassee, FL.

Suttle, N. F., and A. C. Field. 1967. Studies on magnesium in ruminant nutrition. Effects of increased intakes of potassium and water on the metabolism of $\mathrm{Mg}, \mathrm{P}, \mathrm{Na}, \mathrm{K}$, and $\mathrm{Ca}$ in sheep. $\mathrm{Br}$. J. Nutr. 21:819-831.

Tallon, S., I. Berdud, A. Hernandez, M. T. Concepcion, Y. Almaden, A. Torres, A. Martin-Marlo, A. J. Felsenfeld, P. Aljama, and M. Rodriguez. 1996. Relative effects of PTH and dietary phosphorus on calcitriol production in normal and azotemic rats. Kidney Int. 49:1441-1446.

Thilsing-Hansen, T., R. J. Jorgensen, and S. Ostergaard. 2002. Milk fever control principles: A review. Acta Vet. Scand. 43:1-19.

Tucker, W. B., J. F. Hogue, D. F. Waterman, T. S. Swenson, A. Xin, R. W. Hemken, J. A. Jackson, G. D. Adams, and L. J. Spicer. 1991. Role of sulphur and chloride in the dietary cation-anion balance equation for lactating dairy cattle. J. Anim. Sci. 69:1205-1213.

Vagnoni, D. B., and G. R. Oetzel. 1998. Effects of dietary cationanion difference on the acid-base status of dry cows. J. Dairy Sci. 81:1643-1652.

van de Braak, A. E., A. T. Van't Klooster, and A. Malestein. 1987. Influence of a deficient supply of magnesium during the dry period on the rate of calcium mobilization by dairy cows at parturition. Res. Vet. Sci. 42:101-108.

van Mosel, M., A. T. Van't Klooster, F. van Mosel, and J. V. D. Kuilen. 1993. Effects of reducing dietary $\left[(\mathrm{Na}++\mathrm{K}+)-\left(\mathrm{Cl}^{-}+\mathrm{SO} 4=\right)\right]$ on the rate of calcium mobilization by dairy cows at parturition. Res. Vet. Sci. 54:1-9.

Wang, C., and D. K. Beede. 1992. Effects of diet magnesium on acidbase status and calcium metabolism of dry cows fed acidogenic salts. J. Dairy Sci. 75:829-836.

Wiggers, K. D., D. K. Nelson, and N. L. Jacobson. 1975. Prevention of parturient paresis by a low-calcium diet prepartum: A field study. J. Dairy Sci. 58:430-431. 
Appendix A. Published papers reviewed for development of final data set ${ }^{1}$

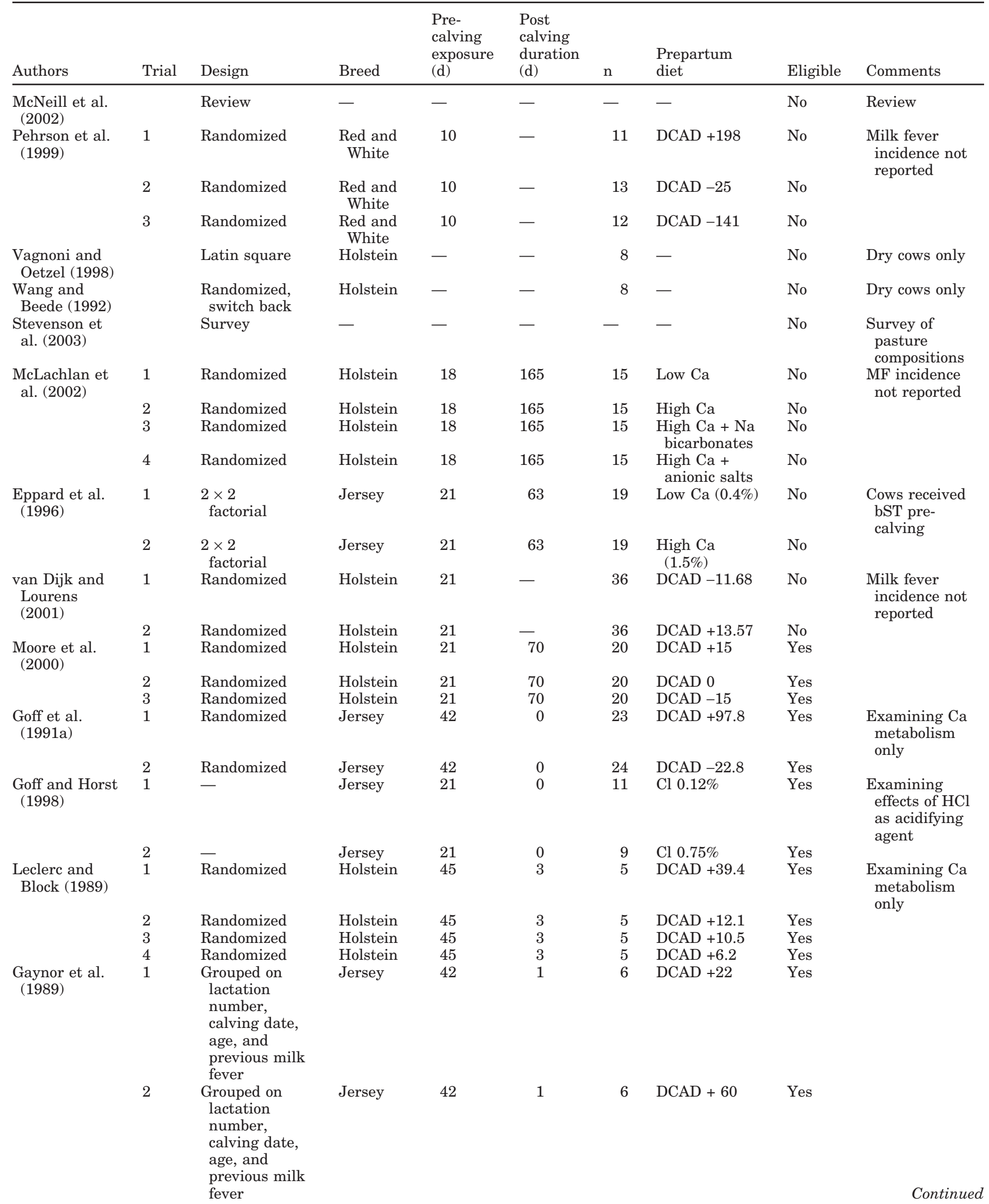


Appendix A (Continued). Published papers reviewed for development of final data set ${ }^{1}$

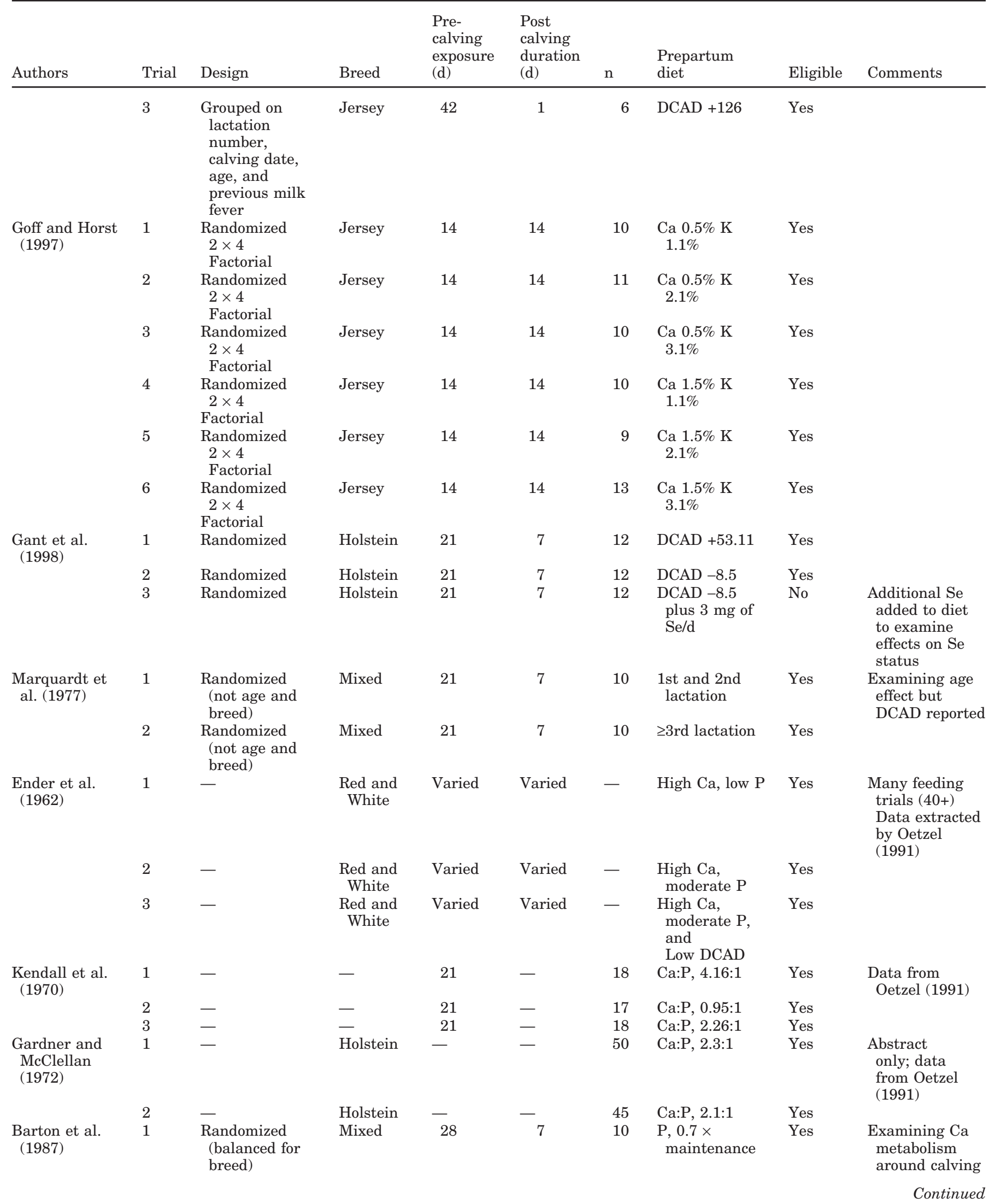


Appendix A (Continued). Published papers reviewed for development of final data set ${ }^{1}$

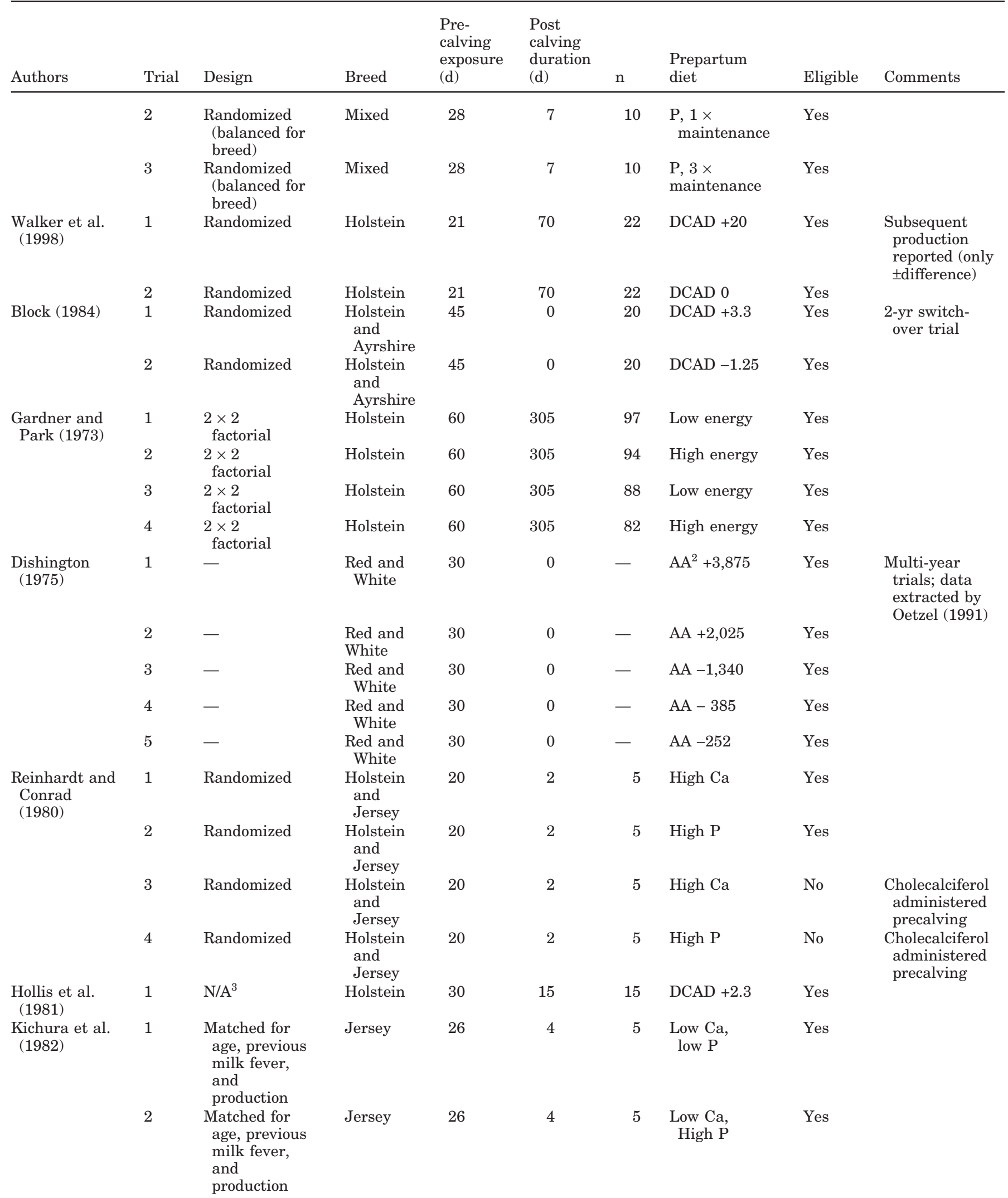

Continued 
Appendix A (Continued). Published papers reviewed for development of final data set ${ }^{1}$

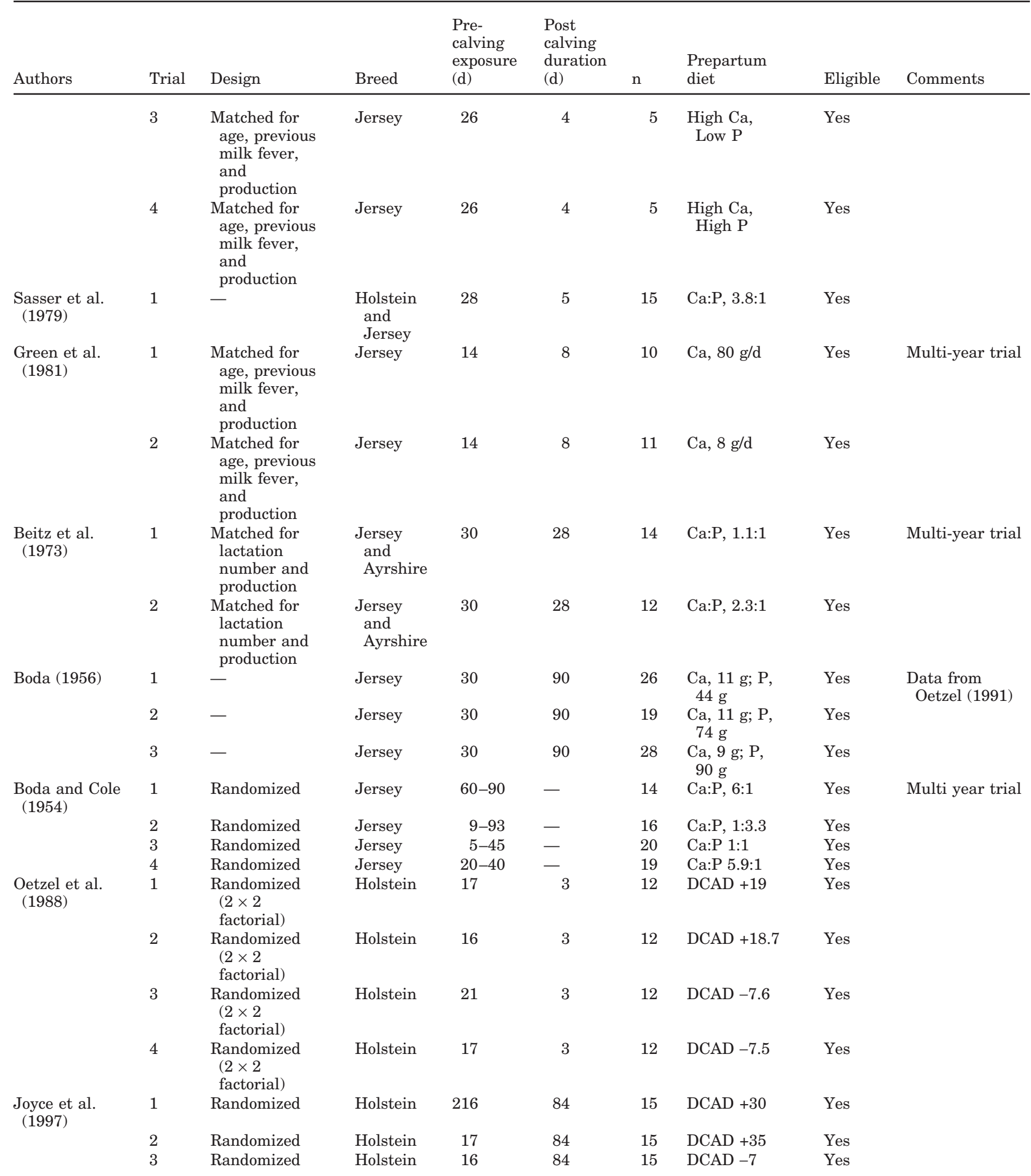


Appendix A (Continued). Published papers reviewed for development of final data set ${ }^{1}$

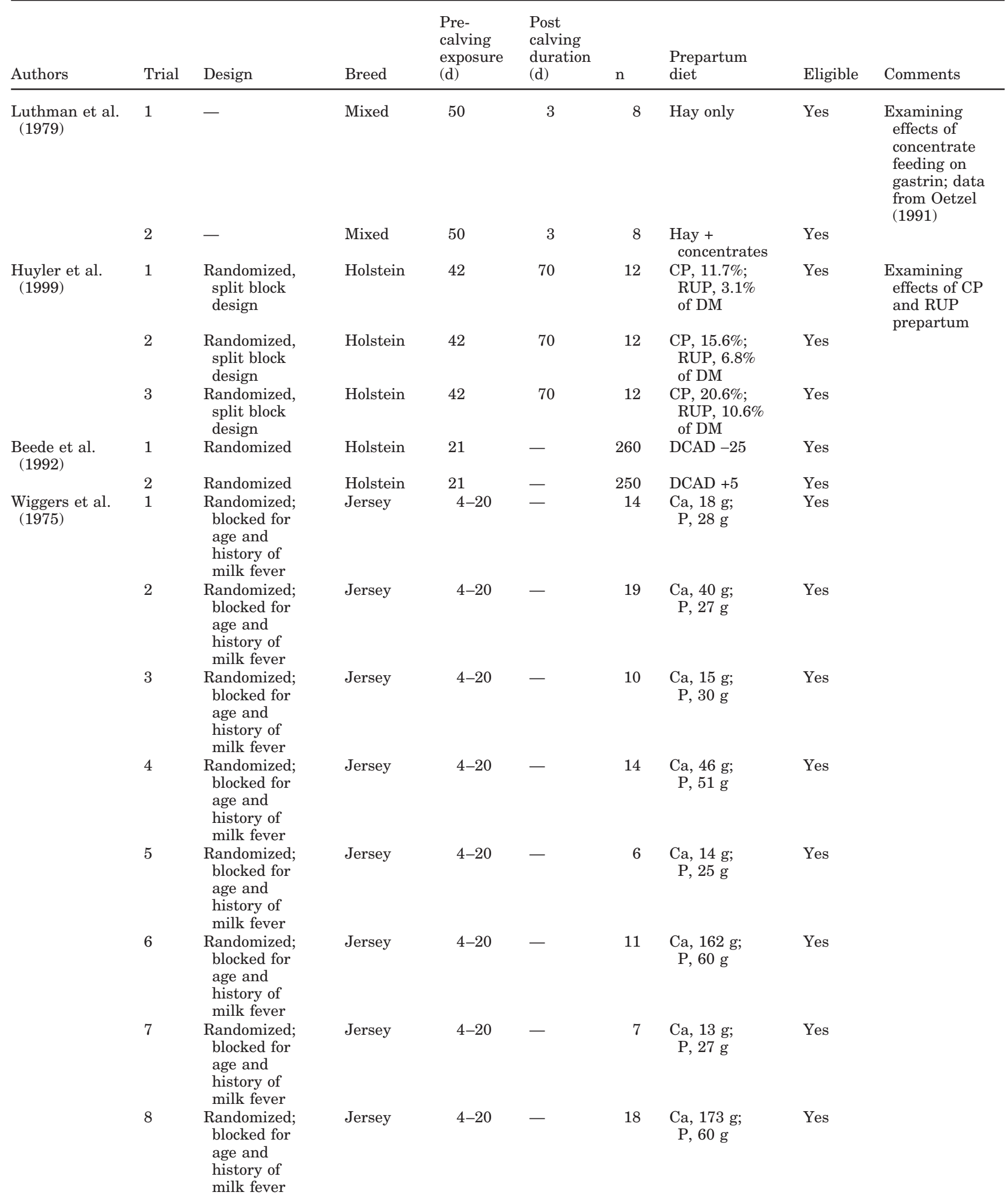


Appendix A (Continued). Published papers reviewed for development of final data set ${ }^{1}$

\begin{tabular}{|c|c|c|c|c|c|c|c|c|c|}
\hline Authors & Trial & Design & Breed & $\begin{array}{l}\text { Pre- } \\
\text { calving } \\
\text { exposure } \\
\text { (d) }\end{array}$ & $\begin{array}{l}\text { Post } \\
\text { calving } \\
\text { duration } \\
\text { (d) }\end{array}$ & $\mathrm{n}$ & $\begin{array}{l}\text { Prepartum } \\
\text { diet }\end{array}$ & Eligible & Comments \\
\hline $\begin{array}{l}\text { Santos et al. } \\
(2001)\end{array}$ & 2 & Randomized & Holstein & 32 & 285 & 53 & $\begin{array}{l}\text { CP, } 14.7 \% \text {; } \\
\text { RUP, } 40 \% \text { of } \\
\text { CP }\end{array}$ & Yes & \\
\hline $\begin{array}{l}\text { van Mosel et } \\
\text { al. (1993) }\end{array}$ & 2 & $\begin{array}{l}\text { Monozygotic } \\
\text { twin pairs }\end{array}$ & Mixed & 49 & 0 & 10 & DCAD +57.3 & Yes & \\
\hline $\begin{array}{l}\text { Tucker et al. } \\
(1992)\end{array}$ & 1 & Randomized & - & 21 & 21 & 60 & DCAD -9 & Yes & \\
\hline $\begin{array}{l}\text { Goings et al. } \\
\text { (1974) }\end{array}$ & 2 & $\begin{array}{l}\text { Blocked for } \\
\text { age, previous } \\
\text { milk fever, } \\
\text { and production }\end{array}$ & $\begin{array}{l}\text { Jersey } \\
\text { and } \\
\text { Ayrshire }\end{array}$ & 14 & 7 & 13 & $\begin{array}{c}\mathrm{Ca}, 41 \mathrm{~g} \\
\mathrm{P}, 34 \mathrm{~g}\end{array}$ & Yes & \\
\hline Oetzel (1991) & & Meta-analysis & - & - & - & - & - & No & Meta-analysis \\
\hline $\begin{array}{l}\text { Enevoldsen } \\
\text { (1993) }\end{array}$ & & Meta-analysis & - & - & - & - & - & No & Meta-analysis \\
\hline $\begin{array}{l}\text { Thilsing- } \\
\text { Hansen et al. } \\
(2002)\end{array}$ & & Review & - & - & - & - & - & No & Review \\
\hline $\begin{array}{l}\text { Roche et al. } \\
(2002)\end{array}$ & 1 & - & Holstein & 17 & 60 & 16 & DCAD +53.5 & No & $\begin{array}{l}3 \text { different } \mathrm{Mg} \\
\text { sources spread } \\
\text { across } 4 \text { trial } \\
\text { groups }\end{array}$ \\
\hline \multirow{3}{*}{$\begin{array}{l}\text { Roche et al. } \\
(2003 \mathrm{~b})\end{array}$} & 2 & $\begin{array}{l}\text { Randomized } \\
\text { (blocked for } \\
\text { age and } \\
\text { previous } \\
\text { lactation) }\end{array}$ & Holstein & $19 \pm 5$ & 21 & 4 & DCAD +16 & Yes & \\
\hline & 3 & $\begin{array}{l}\text { Randomized } \\
\text { (blocked for } \\
\text { age and } \\
\text { previous } \\
\text { lactation) }\end{array}$ & Holstein & $19 \pm 5$ & 21 & 4 & DCAD +51 & Yes & \\
\hline & 4 & $\begin{array}{l}\text { Randomized } \\
\text { (blocked for } \\
\text { age and } \\
\text { previous } \\
\text { lactation) }\end{array}$ & Holstein & $19 \pm 5$ & 21 & 4 & DCAD +69 & Yes & \\
\hline
\end{tabular}

${ }^{1} \mathrm{DCAD}$ in $\mathrm{mEq} / 100 \mathrm{~g}$ of $\mathrm{DM}$ calculated as $(\mathrm{Na}+\mathrm{K})-(\mathrm{Cl}+\mathrm{S})$.

${ }^{2} \mathrm{AA}=$ alkali alkalinity in $\mathrm{mEq} / \mathrm{d}$. Calculated as $(\mathrm{Na}+\mathrm{K})-(\mathrm{Cl}+\mathrm{S})$. 